\title{
EFFECT OF TRAINING THOROUGHBRED FOALS ON THE ANGLE OF THEIR ELECTRICAL CARDIAC AXIS AND MAGNITUDE OF THE VENTRICULAR VECTOR
}

\author{
J. HANÁK \\ Department of Diagnostics, Therapy and Prevention of Animal Diseases, University of Veterinary
} Science, 61242 Brno

Received December 17, 1979

\begin{abstract}
Hanák J.: Effect of Training Thoroughbred Foals on the Angle of Their Electrical Cardiac Axis and Magnitude of the Ventricular Vector. Acta vet. Brno, 51, 1982: $69-73$.

Effect of training upon the angle of the electrical cardiac axis and magnitude of the ventricular vector was investigated in 40 foals from the age of $13-15$ months until their transfer to a training centre at 17-20 months of age. A second group of 40 untrained foals served as control.

Our study failed to show a significant effect of training on the angle of the electrical cardiac axis. Training did, however, affect the magnitude of the ventricular vector due to considerable bilateral ventricular hypertrophy.
\end{abstract}

Foals, age, heart ventricle, hypertrophy.

Better performance of race horses is a goal of breeders in countries with developed husbandry of thoroughbred horses. Great attention is also paid to rearing thoroughbred foals. Its part is a regular, systematic and controlled physical activity of foals, often termed pre-training.

Many schemes have been elaborated for training of foals. However, only few studies take into consideration also the clinical and physiological aspects. In an experiment of Ó csag (1971), foals were trained from the age of $13-14$ months on a racing course with $16-24$ hurdles up to $80 \mathrm{~cm}$ high. During the training period, the hemoglobin content and hematocrit value increased in experimental animals. The later performance of these horses was better as compared to an untrained group. Another method of pre-training was elaborated by Karls on et al. (1973) designed for trotters and based on clinico-physiological grounds. His experimental group, too, showed a better performance than the untrained control group.

Elucidation of changes in the body of a foal during an early started training will undoubtedly contribute to the knowledge of the physiological basis of pre-training. Such knowledge would then serve better organization of training aimed at improved performance of race horses.

The objective of the present study was to pay attention to the cardiovascular apparatus - a limiting factor of performance in the horse. In context with the previous work (Hanák 1981) the differences in vectorcardiogram of regularly trained vs. untrained foals are analysed.

\section{Materials and Methods}

The effect of training on changes in the ventricular vector (angle of the electrical cardiac axis and magnitude of the ventricular vector) was followed in 80 English thoroughbred foals of both sexes.

Group 1 consisted of 40 foals having no regular training. Group 2 (40 foals) was systematically trained from 13-15 months of age until transfer to a training centre. The daily training consisted of an 1-2-hour long forced movement in pace, trot and gallop on a racing course. In all experimental and control foals were the heart sounds clear, well defined, with no additional murmurs 
or arrhythmias. There were no clinical signs of illness observed. The horses were kept and fed in a conventional manner.

The ECG records in tetrahedron system (Hanák 1979) were taken before and after the training period (i.e. at the age of $13-15$ and $17-20$ months). The records were done using a STARTEST (Chirana) apparatus calibrated $10 \mathrm{~mm}=1 \mathrm{mV}$ at $25 \mathrm{~mm} \mathrm{.} \mathrm{s}^{-1}$ speed of the thermosensitive paper. The vector evaluation of the ventricular complex was done by determination of the angle of the electrical cardiac axis and magnitude of the ventricular vector on a cross diagram according to Holzmann (in Perlick and Böhme 1967) in the horizontal (H), transverse (T), sagittal from the right side (Sr), sagittal from the left side (Sl) and sagittal middle $(\mathrm{Sm})$ planes intersecting the centre of tetrahedron.

The results were graphically evaluated and tabulated. For statistical analysis of differences the Stundent's $t$ test was used. The changes in ventricular vector expressed as percentage change during the period under study.

\section{Results}

The angle of the electrical cardiac axis in trained and untrained foals is given in Table 1 . No significant changes in this parameter were observed in either experimental group in the tetrahedron planes during the training period $(P<0.05)$.

Effect of training on the magnitude of ventricular complex of foals is shown in Fig. 1. In untrained foals, no significant changes occurred in either of the tetrahedron planes except for the transverse plane $(P<0.05)$. On the other hand, in the trained foals the magnitude of the ventricular vector increased significantly in all tetrahedron planes except for

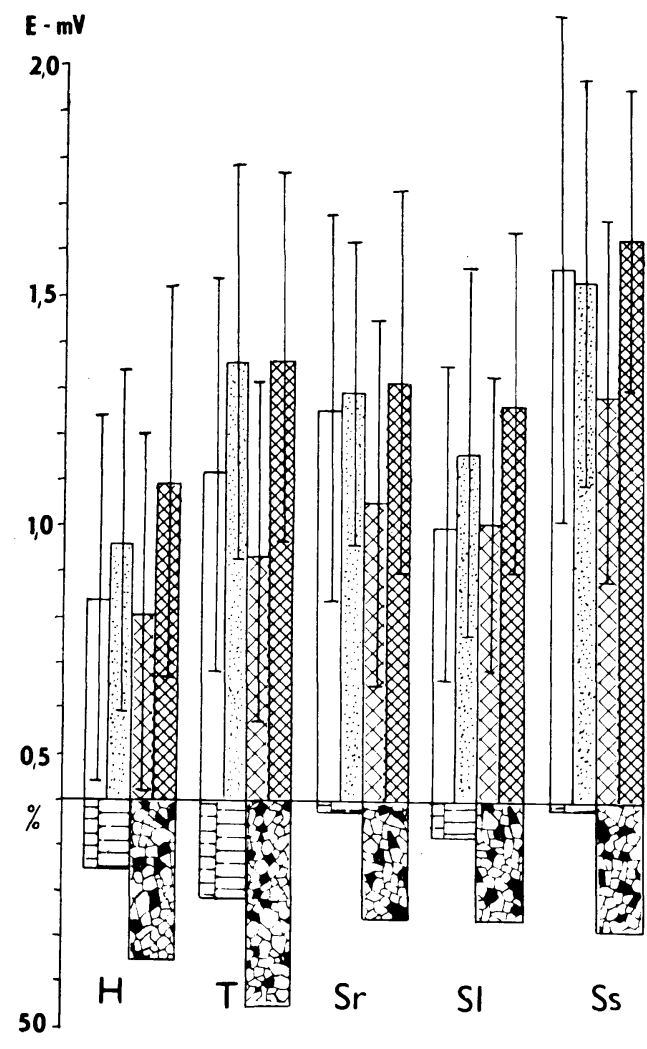
the horizontal plane $(P<0.005)$. In the $\mathrm{Sr}$ and $\mathrm{Sl}$ planes was this enlargement due to training significant $(P<0.05)$, and in the planes $\mathrm{T}$ and $\mathrm{Sm}$ highly significant $(\boldsymbol{P}<$ $<0.01$ ).

Effect of training foals on changes
of their ventricular vector magnitudes

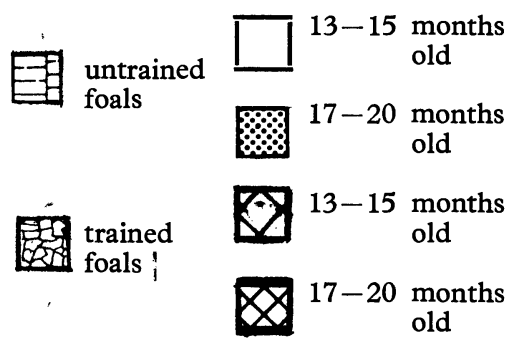

For sagittal middle plane (SM) the designation is Ss. 
Table 1

Angle of the electrical cardiac axis in foals aged 13-15 and 17-20 months, both trained and untrained

\begin{tabular}{|c|c|c|c|c|c|}
\hline Plane & $\begin{array}{c}\text { Age } \\
\text { months }\end{array}$ & $\begin{array}{l}\text { Untrained foals } \\
n=40\end{array}$ & $\mathbf{P}$ & $\begin{array}{l}\text { Trained foals } \\
n=40\end{array}$ & $\mathbf{P}$ \\
\hline $\mathrm{H}$ & $\begin{array}{l}13-15 \\
17-20\end{array}$ & $\begin{array}{r}44.25 \pm 39.51 \\
-84=82 \\
46.15 \pm 22.54 \\
-6=78\end{array}$ & $>0,05$ & $\begin{array}{r}37.20 \pm 35.73 \\
-80 \pm 97 \\
45.35 \pm 28.18 \\
-30-87\end{array}$ & $>0.05$ \\
\hline $\mathrm{T}$ & $\begin{array}{l}13-15 \\
17-20\end{array}$ & $\begin{array}{l}63.60 \pm 20.26 \\
15 \pm 85 \\
62.20 \pm 13.77 \\
40 \quad 81\end{array}$ & $>0.05$ & $\begin{array}{l}68.25 \pm 26.98 \\
20 \pm 114 \\
62.15 \pm 28.98 \\
37 \pm 85\end{array}$ & $>0.05$ \\
\hline - $s$ & $\begin{array}{l}13-15 \\
17-20\end{array}$ & $\begin{array}{l}53.35 \pm 25.99 \\
4 \quad 126 \\
47.10 \pm 16.96 \\
16 \quad 80\end{array}$ & $>0.05$ & $\begin{array}{l}50.95 \pm 32.76 \\
10 \pm 113 \\
50.50 \pm 18.62 \\
24=90\end{array}$ & $>0.05$ \\
\hline $\mathbf{s}$ & $\begin{array}{l}13-15 \\
17-20\end{array}$ & $\begin{array}{l}59.85 \pm 33.41 \\
67 \\
62.20 \pm 26.39 \\
14 \pm 114\end{array}$ & $>0.05$ & $\begin{array}{l}53.20 \pm 31.07 \\
5 \\
63.35 \pm 18.22 \\
35=114\end{array}$ & $>0.05$ \\
\hline $\mathrm{Sm}$ & $\begin{array}{l}13-15 \\
17-20\end{array}$ & $\begin{array}{l}56.50 \pm 24.15 \\
24 \pm 125 \\
54.55 \pm 19.61 \\
20 \quad 87\end{array}$ & $>0.05$ & $\begin{array}{l}52.08 \pm 28.50 \\
-2 \pm 112 \\
55.25 \pm 17.79 \\
26 \quad 102\end{array}$ & $>0.05$ \\
\hline
\end{tabular}

$\overline{\mathbf{x}} \pm \mathrm{S}$

$\min -\max$

A positive effect of training on the magnitude of the ventricular vector is indicated also by percentage increase in magnitude over the period under study. In tetrahedron planes with a significant effect of training on the ventricular vector magnitude ( $\mathrm{T}$ and $\mathrm{Sm}$ ), the vector enlargement accounted for $44.9 \%$ and $27.93 \%$, respectively, while in untrained foals it was only $21.43 \%$ and $1.9 \%$. Similarly, in the $\mathrm{Sr}$ and $\mathrm{Sl}$ planes the increase in vector magnitude was $25.29 \%$ (in both planes) in trained and only $2.17 \%$ and $7.88 \%$ in untrained animals. A large percentage increase in ventricular vector was observed in the horizontal plane in both trained $(35.16 \%$ ) and untrained $(15.00 \%)$ foals. This increase was, however, non-significant in both groups $(P<0.05)$.

\section{Discussion}

In another study (Hanák 1981) we found no more rotation of the electrical cardiac axis in foals aged 13-20 months. Enlargement of the ventricular vector was only observed in the transverse and sagittal left planes. These changes were due to bilateral ventricular hypertrophy causing no deviations in the position of the heart in thorax.

The object of the present study was to differentiate changes in the ventricular vector resulting from forced movement of the foals of this age. No significant changes were found in the angle of the electrical cardiac axis of trained foals as 
compared to the untrained ones or to the experimental animals in our previous study (Hanák 1981).

On the other hand, a highly significant effect of training on enlargement of the ventricular vector was found in the $\mathrm{T}$ and Sm planes, and a significant effect in the Sr and Sl planes. Only in the horizontal plane, there was no significant of training found even if an increase in its magnitude was more than 2 times greater than in untrained foals.

In the transverse plane with a highly significant effect of training the vector enlargement accounted for up to $44.9 \%$ during the study. But also in untrained foals an enlargement of the ventricular vector $(21.43 \%$ ) was observed. This change was also significant as against the values found at 13-15 months of age indicating that besides training also growth of body size make themselves felt as far as the magnitude of the ventricular vector in the transverse plane is concerned (Hanák 1979, 1981). Effect of training on magnitude of the ventricular vector proved significant in the remaining planes and its percentage increase surpassed substantially that found in untrained animals.

On basis of the vector interpretation of hypertrophy and dilatation of heart ventricles, i. e. Brody's effect (Ishikava et al. 1971) it can be stated that enlargement of the ventricular vector is caused by hypertrophy of the ventricular wall. Ventricular hypertrophy which does not change the angle of electrical cardiac axis and increase the magnitude of the ventricular vectors is bilateral, involving both heart ventricles. Comparison of the increase in ventricular vector size in trained and untrained foals revealed a marked effect of training on the bilateral ventricular hypertrophy.

In trained foals a remarkable enlargement of the ventricular vectors is visible both from the right (Sr plane) and from the left (Sl plane) side. On the other hand, in untrained foals the enlargement is more pronounced in the Sl plane indicating a greater contribution of the left ventricle to the hypertrophy.

These data can only be compared to our previous study (Hanák 1981) in which a similar enlargement of the ventricular vectors was observed in foals aged $13-20$ months only in the Tl and Sl planes. It is merely known that the greater metabolic demands in trained animals result in hypertrophy of both heart ventricles as evidenced morphologically as well (Kubo et al. 1974).

It can be concluded that a remarkable bilateral hypertrophy in foals results from training. The changes can be diagnosed by means of the vector analysis of the ventricular E.C.G. complex. This hypertrophy developing under a regular training regimen from early age is a prerequisite of good performance of adult race horses.

\section{Vliv tréninku plnokrevných hříbat na sklon elektrické osy srdeční a velikost komorového vektoru}

Vliv tréninku na sklon elektrické osy srdeční a velikost komorového vektoru byl sledován u 40 hříbat v období od 13-15 měsíců stárí do odchodu na tréninkové ústředí (ve stáríi 17-20 měsíců). Dalších 40 hříbat, která nebyla systematicky trénována, sloužilo jako skupina kontrolní.

Bylo prokázáno, že trénink hř́ibat neovlivňuje signifikantně sklon elektrické osy. Vlivem tréninku však dochází ke zvětšování velikosti komorového vektoru, které je podmíněno vznikem výrazné bilaterární hypertrofie komor. 


\section{Влияние тренировок полнокровных жеребят на наклон электрической оси сердца и величину вектора желудочка}

Влияние тренировок на наклон электрической оси сердца и величину вектора желудочка сердца исследовалось на 40 жеребятах в возрастный период 13-15 месяцев до переведения в тренировочный центрь (в возрасте 17-20 месяцев). Следующие 40 жеребят, систематически не тренированные, служили в качестве контрольной группы.

Было установлено, что тренировка жеребят не оказывает явного влияния на наклон элекртической оси. Под влиянием тренировки, однако, имеет место увеличение вектора желудочка, обусловленное возникновением существенной билатеральной гипертрофии желудошков сердца.

\section{References}

HANÁK, J.: Elektrokardiografický svodový systém $\mathrm{v}$ diagnostice u plnokrevných koní. PhD. Thesis, Brno, 1979, 198p.

HANÁK, J.: Angle of the electrical cardiac axis and magnitude of the ventricular vector in thoroughbred foals. Acta vet. Brno, 50, 1981: 207-212.

ISCHIKAVA, K. - BERSON, H. S. - PIPBERGER, H. V.: Electrocardiographic changes due to cardiac enlargement. Am. Heart J., 84, 1971: 635-642.

KARLSEN, G. G. - POPOV, B. N. - SERGIENKO, S. S.: Opyt intensifikacii zavodskogo treninga rysakov. Naučnye trudy, XXVI, 2, 1973: 135-143.

KUBO, K. - SENTA, T. - SUGIMOTO, O.: Relationship between training and heart in thoroughbred racehorse. Exp. Rep. Eo. Hlth. Lab., 11, 1974: 87-93.

ÓCSAG, I.: A sportló utánpótlást szolgáló csikók ménese elötreningje. Tudományos értesítö, Agrártudományi Egyetem, Gödölö, 38, 1971: 33-58.

PERLICK, E. - BÖHME, H.: Elektrokardiographische Untersuchungsmethoden: Arbeitsmethoden der inneren Medizin. VEB G. Fischer Verlag, Jena, 1967, pp. 100-296. 